\title{
EchoGéo
}

$33 \mid 2015$

Activisme, participation, contestation : la place des habitants dans les processus de patrimonialisation en périphéries urbaines

\section{High-rise Estates, Industrial Tenements And Social Housing : Concerns And Controversies Around Inhabited Heritage Sites}

Introduction

Elizabeth Auclair and Anne Hertzog

\section{(2) OpenEdition}

Journals

Electronic version

URL: https://journals.openedition.org/echogeo/14376

DOI: $10.4000 /$ echogeo.14376

ISSN: 1963-1197

Publisher

Pôle de recherche pour l'organisation et la diffusion de l'information géographique (CNRS UMR 8586)

Electronic reference

Elizabeth Auclair and Anne Hertzog, "High-rise Estates, Industrial Tenements And Social Housing Concerns And Controversies Around Inhabited Heritage Sites ", EchoGéo [Online], 33 | 2015, Online since 30 September 2015, connection on 10 August 2021. URL: http://journals.openedition.org/ echogeo/14376; DOl: https://doi.org/10.4000/echogeo.14376

This text was automatically generated on 10 August 2021.

EchoGéo est mis à disposition selon les termes de la licence Creative Commons Attribution - Pas d'Utilisation Commerciale - Pas de Modification 4.0 International (CC BY-NC-ND) 


\section{High-rise Estates, Industrial Tenements And Social Housing : Concerns And Controversies Around Inhabited Heritage Sites}

Introduction

Elizabeth Auclair and Anne Hertzog

\section{Introduction}

In France, the suburbs and urban peripheries are affected by urban and social phenomena such as metropolisation, de-industrialization, sprawl, renewal, gentrification, impoverishment and tourism. These phenomena can interact, both as causes and effects, with these areas' status as heritage sites: the "construction of heritage" has become a key aspect of today's urban transformation. All five contributions in this issue examine this heritage-making process (or "heritagization") under two angles: the construction of heritage objects in fast-changing territories; and the models of engagement used to facilitate the various stakeholders' (and in particular the residents') participation in the collective management of urban spaces.

\section{Designating popular housing as heritage: a living issue}

2 The contributions in this issue draw from a range of diverse field studies. In the Paris periphery, Sébastien Jacquot and Géraldine Djament-Tran studied Plaine Commune, a metropolitan community in the département of Seine Saint-Denis that comprises of three cities: Saint Denis, Stains and Pierrefitte. In the Lyons periphery, Alain Chenevez investigated an estate called Cité Tony Garnier. Rachid Kaddour examined the SouthEast periphery of Saint-Étienne, with a focus on the evolution of the Beaulieu and Montchovet estates. Finally, through the case of the Arsenal estate, Diego Miralles Buil 
studied the heritage designation of former tenements in the suburbs of Roanne, a midsize industrial city in the Loire département. Although their urban settings differ, these territories bear similarities with each other: for instance a pregnant industrial past, the recent mutations caused by de-industrialisation and urban renewal policies, and common social transformations (gentrification or impoverishment) - all typical of the reconfigurations that have affected the peripheries of French cities. Whether those are "garden cities", "tenements" or "housing estates", these territories have recently joined the long list of urban heritage sites after acquiring this status through complex, multi-stakeholder and sometimes controversial processes.

3 The articles bring a contribution to the emerging field that aims to study the cultural, social, economic and political aspects of heritage-making (Auclair, Fairclough 2015; Gravari-Barbas, ARP, 2015) by questioning its socio-spatial effects. They investigate the role played by space and spatial processes in the relation between urban societies and their heritage and memory, understood as a reconstruction of the past (Veschambre, 2007, Hertzog, 2011). The aim of this issue is to situate the issue of heritage-making within a broader reflection on urban practices (Paquot, Younes, 2007), on the collective appropriation of cities and on the disparities created by this process (Lussault, 2007, 2009). We focused more specifically on the role played by residents in the construction of heritage: this question has already been addressed in depth with regards to antique heritage sites (Melé, 2004; Gravari-Barbas, 2004; Backouche, 2013), but less so in suburbs and urban peripheries, where territories were granted heritage status at a later time and according to different models. The early 00s saw the emergence of demands for "resident participation" as part of urban planning (urban policy, renewal, sustainable development) or heritage policies, as illustrated by recent international frameworks and standards (see the Conventions and Declarations of the Unesco and European Council). The contributions presented here draw an overview of this vision.

In the call for contributions for this issue, we assigned a fairly broad meaning to the terms "urban peripheries", "residents" or "heritage". However we chose to focus specifically on the case of large-scale housing developments and working-class neighborhoods in French cities. This angle emerged from the contributions we received, which all reflected the chronological, categorical and spatial expansion undergone by the notion of heritage since the 1970s (Choay, 1970, Heinich, 2009). It also appeared that terms like "working-class neighborhood", "tenements" and "social housing" all referred to inhabited spaces: this of course implies a reflection on the role played by the population in heritage-making - an angle we chose to suggest in our call for contributions. Finally, beyond the fact that these spaces bring into focus some of the general issues that affect the French banlieues and their residents (Desponds, Bergel, 2015), our interest in the heritage status of suburban working-class housing is also to do with a question that has become particularly sensitive over the past fifteen years, both in academic research and in public debate: the future of high-rise housing developments and that of their residents (Dufaux, Fourcaut, 2004; Pouvreau, 2011; Veschambre, 2008). We do not aim to provide an exhaustive account of the diversity of suburban territories and types of heritage. We will instead focus on specific cases of peripheral territories that have been hit by a crisis, and where community engagement and involvement models have remained very unequal (Deboulet, 2010; Deboulet, Lelévrier, 2014; Desponds et al,. 2014). 


\section{The banlieue: a territory at the heart of today's urban mutations}

5 The term banlieue has multiple meanings, and its primary definition (an area located outside the city's walls) does not do justice to its complexity. This might explain why many researchers have explored this notion and attempted to define it more precisely (Merlin, 2002; Vieillard-Baron, 2001). Although the term covers a range of diverse realities - there are affluent banlieues too - it is used in this issue to refer to disenfranchised urban territories, which are affected by economic problems and social vulnerability (Donzelot, 2006; Stébé, 2010). Equivalent terms can be borrowed from urban planning and development policies: ZUP ("Zones à Aménager en Priorité" or "Priority Development Areas"), social housing areas, ZUS ("Zones Urbaines Sensibles" or "Sensitive Urban Areas"), disadvantaged areas, estates or even ghettos ${ }^{1}$. The new law on Urban Planning now uses the term of "priority areas" to refer to areas that are the object of special measures².

6 More generally, the banlieues are now affected by in-depth transformations, including phenomena of densification (urban renewal, regeneration of redundant industrial land, flagship projects...) and sprawl (construction of new social housing, detached housing developments and trading estates), together with the construction of major infrastructure that accentuate the territory's fragmentation (Zembri, 2005). On an economic and social level, de-industrialization has left a deep mark on existing activities and socio-economical equilibriums. This has led in places to a massive rise in unemployment, leaving many "vacant" spaces. These reconfigurations have created a very clear differentiation between neighborhoods: some of them saw an influx of foreign-born populations along with growing poverty and stigmatization, while others on the contrary were becoming gentrified, with an influx of affluent classes that drove out other more disadvantaged groups (Authier, Bidou-Zahariansen, 2008; Collet, 2015).

\section{Heritage-making: a complex, multidimensional and troubled process}

7 Most contributions describe heritage-making as a complex, multidimensional and systemic process that involves multiple categories of stakeholders, each with their own and often conflicting agendas. Conceptually speaking, the authors have adopted different approaches. Géraldine Djament-Tran and Rachid Kaddour situate their work within a social and critical geography of heritage, with a focus on stakeholder interplay and domination relations in heritage-making processes, in the lineage of Vincent Veschambre's late 1990s work. This approach has also been an influence on Diego Miralles Buil's work: his contribution considers the link between heritage and territory, or between heritage-making and territory-making, working from the fundamental notion of spatial appropriation (Di Méo, 1994). Miralles Buil's contribution associates the process by which working-class estates are granted heritage status with the complex re-territorializing of urban spaces, which has followed on from its territorializing (the design of tenements to meet the needs of a national economic project, the arsenals) and de-territorializing (caused by the State's disengagement, the "privatization" of real estate and their social consequences). Heritage-making is seen by the author as a new territorial "model" that can heighten past inequalities and contrasts: by emphasizing the specificities of former tenements, these processes tend 
to hinder their "normalization" and to stop them from blending in both visually and socially with the rest of the city.

8 Alain Chenevez develops an analysis that aims to "convey some groups' claims to heritage justice". Chenevez follows Luc Boltanski and Laurent Thévenot's theory of "the economies of worth", and transposes to the construction of heritage Becker's analysis of the processes that preside over the creation of a work of art. He shows that heritage-making as an "interpretative and argumentative process amounts to the construction of a cause" by a collective entity. This work involves a network of "agents and operators that interact through micro-strategies, unlikely alliances and controversies, struggles and conflicts, but also through basic consensus on the aim to be pursued."

9 Sébastien Jacquot addresses the question of the role played by residents in heritagemaking, bearing in mind Daniel Cefai's work on social activism and its attempts to "articulate places with moments, people and artifacts". Jacquot draws parallels between this perspective and that of Jacques Rancière, who "articulates politics with community building and the "symbolic construction of society". In particular Rancière's notion of a "distribution of the sensible", which refers to "a system of sensible evidence that reflects both the existence of a common realm and that of divisions that define various groups' respective roles and shares" proves very stimulating (Rancière, 2000, quoted by Jacquot in this issue). Using these insights, the author considers heritage policies from the perspective of the community, considering these policies' impact on "shaping various experiences, by considering the ways in which residents are defined, along with their place and agency". In this sense, Jacquot's perspective is rather close to that developed by Alain Chenevez.

The authors all address the conflicts arising from divergent uses of heritage and from the "heritagization" of urban spaces. These conflicts are examined in the context of urban suburbs and peripheries, through examples illustrating the diverse ways of relating to heritage, as well as the antagonisms and tensions caused by these spaces' growing social diversity. The contributions measure the respective weight and place of each population group, examine which urban objects and projects are rejected or on the contrary accepted, and question the new scales on which these conflicts are occurring. For instance, Géraldine Djament-Tran's contribution shows how the categorical and territorial expansion of the very notion of heritage has contributed to a shift of heritage-related conflicts from urban centers towards the peripheries. Urban planning's new scales and concepts (integration of peripheral territories with central spaces, "Greater Paris" project $\left.{ }^{3} . ..\right)$ have, together with the emergence of new ways of living in the periphery (growing mobility, new residential aspirations, feeling of relegation or exclusion, scattering of living spaces...), created new conflicting forms of appropriation of urban spaces and new conflicts around heritage. Current urban planning agendas (urban renewal policies, eco-districts...) and the growing weight of some economic stakeholders in spatial transformations (promoters, large industrial groups settling in tax-free zones or disaffected areas...) have transformed the equilibriums between players. As a result, some groups have become increasingly vulnerable and are struggling to access, produce and defend "their" heritage. Several articles thus highlight the exclusion or marginalization of some groups, for the benefit of other categories of actors who have imposed their vision of the city and its future. 


\section{Identity, justice, acknowledgement: (alter)- heritagization}

11 The various approaches proposed by the authors are particularly stimulating in helping us understand heritage-making's role as a model for the representation and organization of common and collective commodities in the city - and therefore as an important dimension in today's urban life ${ }^{4}$. The contributions remind us that heritagemaking is the cultural, social, political and sensory expression ${ }^{5}$ of a relation to time and space, to the Other and the Self. The authors elaborate on this relationship in terms of appropriation or attachment to places, but also in terms of an individual's positioning in space. Making heritage means creating categories (museums) and setting boundaries (preserved areas), but also positioning oneself with respect to an alterity. In the case of the peripheries or banlieues, this position - which can sometimes be militant - with respect to a (dominant) center is one of the main challenges posed by territorial heritage-making. Diego Miralles Buil shows that one of the key challenges posed by the heritagization of the Mably industrial tenements has been to improve connections between this peripheral and marginal area and the rest of the city - all in the name of "urban cohesion" -, while also asserting the town's specific local identity against that of the neighboring city of Roanne. Géraldine Djament-Tran looks back at the efforts made to assign a positive value to the banlieue undertaken, as part of Seine-Saint-Denis' heritage and tourism policies: these policies' objectives were both metropolitan (to reposition peripheral territories) and local (to create a sense of belonging and pride of living in territories that were often seen as "marginal"). Based on the case of SeineSaint-Denis, Sébastien Jacquot presents the emergence of the category of "suburban heritage", which he defines as "elements of heritage that help form a consistent image of the suburbs and their history - which is not to be confused with suburb-based heritage". He stresses that "policies aimed at enhancing the value of heritage has become a way of expressing a territory's specificity, at odds with Parisian centralism: this category of 'suburban heritage' is not just a tool of analysis, but an identity embraced by these new actors".

In the case of the Tony Garnier estate's newly acquired heritage status, although there isn't an explicit claim to a banlieue identity, the idea of breaking with centrality through the construction of new heritage representations that are specific to estates and social housing areas is clearly embraced. Alain Chenevez shows how the Tony Garnier estate's classification as heritage, which had been initiated with the renovation of derelict buildings, created an "active sense of cohesion that was perceived as relevant and wellfounded". This sense of cohesion results from action and expression modalities that systematically embrace a departure from the conventional social and territorial frameworks set by art, heritage and culture. For instance, murals are seen as an alternative to more legitimate forms of artistic expression, and high-rise blocks are seen as "counter-monuments" (Young, 1992), with the support of entities that exist outside from cultural institutions (Prefect, collectives of mural painters, sociologists, local authority workers...). In addition, the linguistic twist that consisted in repurposing the term "museum" to refer to the area amounts to an act of resistance, as defined by Michel Foucault: a category of discourse normally used to refer to the ultimate place of legitimate and elitist culture is applied to a place that does not present its "normative" characteristics and doesn't respond to the standards of cultural institutions (ICOM, Department of Culture, etc.). Finally, the creation of "collectives of residents" is 
perceived as the embodiment of a form of heritage justice: the power of the experts can be rebalanced in favor of "shared" expertise or even delegated to the residents alone.

This contribution shows how the idea of a departure - from the center, the norm... - is being claimed as a new form of legitimation: heritage-making is to be understood as the making of an alter-heritage. This process calls for a new definition of heritage (which has been an emerging trend over the last few decades), just like its development involves new categories of actors and practices that are seen as alternative. Because it is perceived as "ordinary" and "mundane", suburban heritage is often associated with "everyday" territories and "banal" spaces. These new heritage representations are conveyed for instance by "La Maison de Banlieue et de l'Architecture" (House of Suburbs and Architecture) in Athis Mons, or by the Eco-museum of Val de Bièvre in Frênes, two venues that belong to a network called "Les Neufs de Transilie" in the Paris region (Auclair, 2015). These players all aim to question "what should be seen as heritage by the residents", reject the holistic and conventional definition of heritage, and challenge the established social relations of domination (center vs. periphery, elite vs. people, experts vs. residents, etc.). The focus is not anymore on the aesthetic, historical or architectural dimensions but on "what matters to the residents" and "what they care for" (Auclair, 2014d).

The contributions emphasize the ideological dimension of heritage, as well as the social and symbolic aspects of heritage-making in peripheral territories. The process is seen as an opportunity for some social groups "who have not inherited any heritage objects they can relate to (castles, hotels, monuments connected to the exercise of power...) to build themselves a heritage of their own, a visibility and a legitimacy": heritage grants them " $a$ right of presence and a legitimacy in the city" (Veschambre, 2008).

And indeed in vulnerable peripheral areas affected by social and spatial segregation, physical and symbolic fractures appear between residents and their territory. The increased distance between people's place of residence and place of work, and between their place of residence and retail, culture and leisure structures have contributed to the population sometimes losing its frames of reference (Auclair, Vanoni, 2001). These processes can create a sense of indifference and even rejection in the population towards their neighborhood or their city. In some cities, artistic, cultural and heritagebased projects have been used to support rehabilitation processes. Research has evidenced the part played by culture in the development of urban territories (Bruston, 2005; Kahn, 2009; Ba, Zentelin, 2010) and the specific role of cultural projects in the social transformation of disadvantaged areas (Chaudoir, De Maillard, 2004; Auclair, Brunet, 2008). Today's cultural and heritage projects have multiple objectives: to help alleviate social segregation phenomena, to change perceptions of the banlieues (in outsiders and in the residents themselves), to instil a sense of pride in the population, to foster a sense of belonging in the territory, and to thus contribute to building a genuine territorial identity (Auclair, 2003, 2006, 2010).

16 This issue presents five analyses of urban territories that show similarities on a historical level but differences in terms of heritage: their "trajectories" - or, to quote Alain Chenevez, "heritage careers" - are contrasted. The differences lay in the preservation/demolition processes (Beaulieu vs. Montchovet in Saint-Étienne), in the varying levels of resident engagement (Pierrefitte vs. Saint-Denis in Plaine Commune) or in the diverging interpretations of the past that underpin the built environment's preservation/development (Office HLM vs. residents in Saint-Étienne). Quite obviously, 
these contrasted "heritage careers" are due to the varying fortunes of French peripheries, while reversely impacting these evolutions. The authors in this issue show that while for decades, the classification of urban territories as heritage has acted as a contrasting and differentiating factor between city centers ("preserved", "museumified", "touristicized") and peripheral territories (Veschambre, 2007), it does however now act as a driver of differentiation and in some cases of fragmentation within the peripheries themselves (Gervais-Lambony, 2007).

The researchers highlight the processes through which territories can acquire or lose value, generating spatial inequalities on multiple scales (Backouche et al., 2011). Heritage-making involves selection and development processes that bring to light the underlying symbolic hierarchies at play in urban representations (as perceived by residents, political representatives, developers, etc.), but also in public action and urban projects, with an knock-on effect on urban transformations. In this respect, the authors provide a few examples - in particular in Saint-Étienne - of cases where the classification of housing estates as heritage sites also carries an element of "symbolic violence" towards certain categories of the population, to use a term coined by Pierre Bourdieu.

\section{From spontaneous engagement to supervised participation, what part can residents play in heritage- making?}

18 In addition to the many existing studies on governance issues, recent research projects have examined the renewal of resident participation theories and strategies, with the emergence of new forms of participative democracy and concepts such as "empowerment" and "capacity building" borrowed from the English-speaking world (Blondiaux, 2008; Nussbaum, 2011; Baqué, Biewener, 2013). Loïc Blondiaux explains that in France and in most Western countries, this concept was not new: it was a "revival" of a theme that had been developed in the sixties and seventies, and championed at the time by associations, trade unions and political movements (Blondiaux, 2012). Today on the contrary, resident participation is the result of a topdown process, which is driven by elected authorities through multiple structures and events such as consultative meetings, forums or conferences: the term of "participative injunction" is often used to refer to this pressure.

Resident participation is clearly embedded in most public policies, especially in the fields of urban planning and environment. Since 1991's Outline Act on urban planning, where resident participation is defined as an essential principle, this question has regularly been brought up by urban planning authorities, although in 2004 it appears to have been discounted by the ANRU (National Agency for Urban Renewal), at least for the first years of the program. Various pieces of research have highlighted the gap between discourses that promote resident participation, and the reality where populations are hardly ever involved in the projects that affect them (Desponds et al., 2014). In the wake of a well-publicized report highlighting the need to overhaul resident participation (Baqué, Mechmache, 2013), a new 2014 Law stated the principle of co-construction in urban planning policies, working with residents through the creation of community councils. Resident participation is equally valued in urban 
planning, environment and sustainable development, where numerous mechanisms and tools have been created: development councils for local authorities, compulsory consultations to design land use plans, compulsory participatory actions for the local Agenda 21 program... In addition, the National Commission for Public Debate ("Commission Nationale du Débat Public"), which became an administrative authority in 2002, and Community Councils (Conseils de quartiers) set up in cities of over 80,000 inhabitants by the 2002 Bill on local democracy have contributed to structuring participative mechanisms.

As for resident participation in cultural and heritage policies, the population's input seems to have always been at the heart of reflections, even though concepts and approaches have evolved with the various cultural policies. In particular, there was a shift from the "democratization of culture" to "cultural democracy": the aim became to develop individual and collective cultural practice and to involve people, not just as "audiences" of a cultural offering but as active participants in local cultural life (Urfalino, 2004; Poirrier, 2010). More recently, new debates appeared around resident participation in cultural life with many research projects analyzing these recent evolutions (Bordeaux, Liot, 2012; Gazeau, 2012). Actors and researchers are presenting new concepts such as that of "cultural rights": rather than defending a so-called right to culture, the focus is on promoting cultural rights. Those include for instance the right to take part in cultural life in any way possible (Fribourg Declaration, 2007). This conception of resident participation opens up new perspectives while raising a number of issues (Auclair, 2014c).

21 Analyzing heritage-making from the angle of "resident participation" is not just the effect of novel institutional or academic concerns. This angle is justified by a reflection on the part played by the residents in urban peripheries, outside of "museified" historic centers. The action of residents, often from the middle or upper classes, has greatly contributed to the emergence of "heritage awareness" in central neighborhoods (Tomas, 2004; Melé, 2004; Veschambre in Gravari-Barbas, 2004) as attested by the creation of many heritage preservation societies in historical districts: the Commission for the Old Paris ("Commission du Vieux Paris") created in 1897, the Association for the Rebirth of the Old Lyons ("Association Renaissance du Vieux Lyon") created in 1946, Préservation and Future of Troyes ("Sauvegarde et Avenir de Troyes") in 1963... Their work was often complemented by other heritage promotion models, delivered by new categories of stakeholders: heritage preservation institutions, public bodies, tourist boards... However, as shown by Alain Chenevez and Sébastien Jacquot in this issue, peripheral or suburban spaces did not attract the same level of interest from heritage institutions (national Departments of Culture and Heritage, Regional Councils, etc.) until the late $90 \mathrm{~s} / 00 \mathrm{~s}$.

Working from field work completed at Plaine Commune, with a specific focus on the residents' perspective, Géraldine Djament-Tran outlines three different modes of relation between residents and their heritage, which she analyzes as a function of their relation to their living space: active preservation, non-preservation/anti-heritage action, or participation to the institutional promotion of heritage. The comparison between the cases of the estates Cité Meissonnier in Saint-Denis, Cité des Poètes in Pierrefitte and Cité Jardin in Stains concludes that the role of residents shouldn't be overrated, and actually plays a minor part. This trait, which is characteristic of working-class neighborhoods, is linked to a more global phenomenon of "disaffection" 
among the working class, to poverty and in some cases to some resident's poor sense of belonging - which also raises the question of immigrant heritage, or rather that of the heritage of the populations of foreign origin who live in these areas. However, "antiheritage action" (with for instance demolition plans in Pierrefitte) is for the most part justified by the buildings' state of dilapidation and unfitness for purpose. The hypothesis according to which "heritage awareness" is determined by class and "cultural capital" is also explored by Diego Miralles Buil, looking at the Arsenal neighborhood and its social divisions, which date back to the area's construction. The author observes a similar level of indifference to the workers' tenements in the working classes living in the Mably side of the estate - including former factory workers who are long-time residents of the area - as in the newcomers who live in the more gentrified Roannes side of the estate. These new populations know nothing about the area's past, and are more concerned with transforming the former tenements than with restoring them or preserving their authenticity. This awareness does however exist in Mably, a working-class town at the edge of Roanne, but it doesn't originate from the population: it is orchestrated by the town authorities and in particular by the Mayor, who has initiated the restoration of a few houses and designed roads and green spaces to preserve the old urban arrangement, in the name of heritage preservation. As with Plaine Commune (as analyzed by Géraldine Djament-Tran), the author insists that "heritage activism" is mostly championed by the local authorities.

\section{Actions and reactions of heritage institutions: uses of heritage and heritage-making}

All authors mention the decisive role played by local representatives, and in particular Mayors, along with experts and in particular architects. Social housing, tenements and high-rise estates have been labeled as heritage sites by these categories of stakeholders, who are often outsiders to these territories, without any involvement from the local population (and in some cases, against their action).

Alain Chenevez looks at the case of the Tony Garnier estate in the eastern periphery of Lyons, which was listed under the initiative of some of its tenants, including a few particularly active individuals. His paper also retraces the actual "appropriation" of the process by institutions - of which Chenevez is himself a representative, as the author of an academic and cultural project that translates the professionalization and institutionalization of a heritage site that has long been seen as minor or even illegitimate in the eyes of cultural institutions. Yet a shift occurred in perceptions of the site, thanks to its labeling as UNESCO heritage and to the emergence of new agendas such as touristic development and metropolitan planning (Greater Lyon, followed by Lyon Métropole): this institutional re-appropriation has led to the marginalization, and even to the eviction, of some residents through the rehabilitation process.

The articles therefore challenge the way the notion of heritage "co-production", as championed by a number of international texts ${ }^{6}$ including the Faro convention (which to this day has not been signed by France), is implemented in practice (Fairclough et al, 2014). The articles also examine the diversity of roles played by the institutions with regards to resident action (as a spark, a driver, a support, a hindrance...), and highlight the new forms of partnerships that have appeared between these institutions and the 
local populations around the question of urban spaces' classification as heritage. The articles reflect the diversity of stakeholders involved in such processes - community groups, museums, cultural and heritage institutions, local authorities or managerial bodies - a source of "polyphony", or more frequently one of "cacophony", as noted by Rachid Kaddour.

Urban transformation is a challenge to heritage institutions in the current context of metropolization, periphery reconfiguration (Greater Paris, urban renewal, widening of the wealth gap, creation of urban communities...) and new urban planning agendas. The diversity of the populations, of social groups and territories is factored into the design of "participative" mechanisms, serving new objectives such as "sustainability", "diversity" and "cohesion", in an urban space that is often perceived as "fragmented", "multi-centric" or "scattered". The rise of social and political demand in the population has raised new questions amongst heritage professionals on the role that residents should be allowed in the definition of urban heritage (Delarge, 2011) and in the methods used to identify and list it (Auduc, 2008, 2011; Auduc, Faure, Hertzog, Auclair, 2014). This issue highlights how the notion of "resident", which has become the object of renewed analyses in social sciences (Anquetin, Freyermuth, 2009; Tricot, 2014; Auclair, Faircough, 2015), is being used in the discourses of cultural actors, heritage and urban planning professionals and elected representatives. For instance, Sébastien Jacquot looks at the various "ways in which residents are referred to and categorized by heritage development policies". The author distinguishes between five "resident figures", defined by the role they are granted in touristic heritage development policies: beneficiaries, witnesses, tourists, ambassadors or participants/co-producers. Working from the analysis of the 2012-2016 community-based tourism program in Plaine Commune, the author shows how a differentiated use of the notion of resident has blurred the line between residents and tourists. The emergence of "residenttourist" category has helped construct the concept of an everyday "rediscovery" of familiar territories, facilitating a process of "re-appropriation" that plays a key part in current participative heritage policies. The mention of "residents" in participative policies is thus used to define the place granted to each individual in their city, the part they are expected to play and their agency within the territory.

Diego Miralles Buil shows that the Mably industrial workers' tenements have been listed as heritage under the initiative of the Communist city authorities, with residents acting mostly as beneficiaries of this action. Yet a segment of this population, comprising of "former factory workers", has been used as "witnesses" (through the collection of their testimonies on the neighborhood) and seen as the bearers of a piece of "working-class memory" - an unlikely avatar of the concept of a "class memory" (Verret, 1984) - in the context of the city's socio-spatial reorganization.

This issue also exemplifies a number of participative practices implemented in working-class neighborhoods, including the collection of "resident memories" as heritage objects. These institutional practices, which are now systematically applied in urban renewal projects, have raised a number of questions and critiques (Foret, 2007). Amongst those is the risk of "instrumentalization" (Auclair, 2014 a et b), also mentioned by Rachid Kaddour's article on Saint-Étienne. The author distinguishes between two types of heritage-making activities, with unequal levels of output. The first type of activity, based on "the history of the social housing movement" in Beaulieu, has produced an accomplished output (buildings are preserved and listed, 
memories are valued and made visible within public spaces), using a model that is based on a highly selective sense of memory, on the blotting out of entire parts of recent urban history and on the eviction of certain memories. On the contrary, in Monchovet, residents' testimonies and memories were collected when the estate was demolished in 2000.

Are memories being turned into heritage, creating what Rachid Kaddour calls "immaterial heritage"? For the residents who take part in such projects, stories, drawings and other outlets can provide a medium for important experiences, with opportunities to both express and feel emotions. This concept can also help communicate the importance of the community (and in particular the North-African community), or the part played by poverty, violence and community activism in today's modes of dwelling. However, for institutional stakeholders, these stories are seen as illegitimate because they are perceived as negative and "dissonant" (ghettoization, segregation, urban "counter-models"...): as a result, these actions are less visible and more vulnerable. The author draws an opposition between "lasting and well-executed projects, that have been created with sufficient resources: film, books, show apartments..." dedicated to the memories of Beaulieu's first residents, and on the other hand "cheap, ephemeral projects: talks at community events, basic printouts distributed to a very narrow audience" dedicated to the memories of poorer residents who have moved in more recently. The testimonies of North-African tenants in Montchovet, an estate seen as a "ghetto" can, just like the stories of collective struggles against the institutions to secure equipment for the neighborhood or fight demolitions, be seen as "counter-memories" (to quote Michel Foucault): these are blotted out and even "silenced" in public space, which stops them from becoming heritage for other people outside of the residents themselves.

The idea according to which heritage development, by refreshing people's knowledge of territories that have long been ignored, denigrated or stigmatized (Beaulieu in SaintEtienne, the workers' tenements in Mably, the Cité Jardin estate in Stains), can generate better recognition for the residents by reintegrating them to the great urban narrative and restoring their visibility within urban spaces is a widely accepted fact that appears recurrently in actors and researchers' discourses. In this sense, heritagemaking or "heritagization" is the embodiment of an urban "spatial ideology" (as defined by Michel Lussaut in 2007) that presides over a number of urban planning practices and policies. And yet, as illustrated by the contributions in this issue, the disparities in heritage-making processes, and the symbolic and material value they create, both contribute to the perpetuation of "systemic inequalities" (Veschambre, 2007, 2008).

\section{BIBLIOGRAPHY}

Anquetin V., Freyermuth A., (dir.), 2009. La figure de l"'habitant". Sociologie politique de la demande sociale. Rennes, PUR, $184 \mathrm{p}$. 
Auclair E., Fairclough G., (dir.), 2015. Theory and practice in heritage and sustainability: living between past and future. London Routlege.

Auclair E., 2015. Ordinary heritage, participation and social cohesion in the banlieues of Paris. In Auclair E., Fairclough G., (eds), Theory and practice in heritage and sustainability: living between past and future. London, Routlege.

Auclair E., 2014a. Artistes, habitants et démolition : le rôle des projets culturels dans la rénovation urbaine. In Desponds D., Auclair E., Bergel P., Bertucchi MM., (dir), Les habitants, acteurs de la rénovation urbaine? Rennes, PUR, p. 111-126.

Auclair E., 2014b. Les projets mémoriels en banlieue : participation ou instrumentalisation des habitants? Revue Francosphères, $n^{\circ} 3-2$.

Auclair E., 2014c. Diversité culturelle et droits culturels, atouts et ambiguités des nouveaux concepts mobilisés dans les quartiers. In Bertucci M.M., Boyer I., Bulot T. (dir), Diasporisations sociolinguistiques et précarités. L'Harmattan, p. 145-162.

Auclair E., 2014d. Paysages ordinaires de banlieue : reconnaissance et appropriation par les habitants. Paysages urbains d'Ile de France, Paris, Somogy éditions d'art.

Auclair E., 2010. L'action culturelle peut-elle constituer un vecteur d'intégration sociale et devenir un véritable outil de valorisation du territoire? In Hameth Ba A., Zentelin J.L. (dir), La dimension culturelle du développement. Dynamiques de valorisation et de dévalorisation des territoires urbains. L'Harmattan.

Auclair E., Brunet F., 2008. Projets culturels et développement social des quartiers, retours d'expériences et perspectives. Recherche Sociale, $n^{\circ} 187$.

Auclair E., 2007. La culture et les quartiers populaires. Diversité, $n^{\circ} 148$, p. 53-59.

Auclair E., 2006. Comment les arts et la culture peuvent-ils participer à la lutte contre les phénomènes de ségrégation dans les quartiers en crise ? Hérodote, $\mathrm{n}^{\circ} 122$.

Auclair E., 2003. Le développement culturel comme outil de promotion d'une identité territoriale, ou comment les acteurs locaux se saisissent de la culture pour faire émerger un territoire. In Gravari-Barbas M., Violier P. (dir), Lieux de Culture, culture des lieux. Presses universitaires de Rennes.

Auclair E., Vanoni D., 2001. Ville émergente, le fonctionnement de la multicentralité. Recherche sociale, $n^{\circ} 157$.

Auduc A., 2008, Patrimoines d'Ile-de-France. Rencontre des histoires, des populations et des territoires. Actes du colloque régional, 6-7 décembre 2007, Région Île-de-France, Somogy Editions d'art, $208 \mathrm{p}$.

Auduc A. (dir), 2011. Ces patrimoines qui font territoire. Actes du colloque régional, 24-25 novembre.

Auduc A., Faure J., Auclair E., Hertzog A., 2014. La patrimonialisation en question. Entre culture experte et culture habitante. Projet de recherche sélectionné dans le cadre de l'appel à projets du GIS IPAPIC 2013 : « Pratiques interculturelles dans les processus de patrimonialisation », Ministère de la Culture et de la Communication. Voir Ministère de la Culture et de la Communication, 2015, Culture et Recherche, 130, p. 98-99.

Authier J.-Y., Bidou-Zahariansen C. (dir), 2008. La gentrification urbaine. Espaces et sociétés, $n^{\circ}$ 132-133.

Backouche I., Ripoll V., Tissot S., Veschambre V., 2011. La dimension spatiale des inégalités. Rennes, PUR. 
Backouche I., 2013. Aménager la ville. Les centres urbains français entre conservation et rénovation (de 1943 à nos jours). Paris, A. Colin, 448 p.

Baqué M.-H., Biewener, C., 2013. L'empowerment, une pratique émancipatrice. La Découverte.

Baqué, M.-H., Mechmache, M., 2013. Pour une réforme radicale de la Politique de la ville. Rapport remis au gouvernement.

Blanchard, P., 2013. Histoires, patrimoine et mémoires dans les territoires de la politique de la ville. Rapport remis au Ministre délégué à la ville François Lamy.

Blatrix C., 2009. La démocratie participative en représentation. Sociétés contemporaines, $\mathrm{n}^{\circ} 74$.

Blondiaux L., 2008. Le nouvel esprit de la démocratie. Actualité de la démocratie participative. Le Seuil.

Bordeaux M.-C., Liot, F. (dir), 2012. La participation des habitants à la vie artistique et culturelle. L'Observatoire, $\mathrm{n}^{\circ} 40$.

Bruston A. (dir), 2005. Des cultures et des villes, Mémoires au futur. Éditions de l'Aube.

Callon M., Lascoumes P., Barthe Y., 2001. Agir dans un monde incertain, essai sur la démocratie technique. Paris, Seuil, $358 \mathrm{p}$.

Carrel M., 2013. Faire participer les habitants, Citoyenneté et pouvoir d'agir dans les quartiers populaires. ENS Éditions.

Chaudoir P., Maillard J. (dir), 2004. Culture et politique de la ville. Éditions de l'Aube

Choay F., 1970. L'Allégorie du patrimoine. Paris, Ed du Seuil

Collet A., 2015. Rester bourgeois. Les quartiers populaires, nouveaux chantiers de la distinction. Paris: La Découverte.

Deboulet A., Lelévrier C., 2014. Rénovations urbaines en Europe. Rennes, PUR.

Deboulet A., Nez H., 2013. Savoirs citoyens et démocratie urbaine. Rennes, Presses Universitaires de Rennes.

Deboulet Agnès et al., 2010. La rénovation urbaine entre enjeux citadins et engagements citoyens. Rapport de recherche, Éditions du Puca.

Delarge A., Ecomusées du Val de Bièvre, 2011. Le patrimoine de banlieue existe-t-il ? Actes de la journée d'étude à l'écomusée du Val de Bièvre, 2 février 2010.

Desponds D., Bergel P., 2015. Les « banlieues françaises » : des dynamiques complexes derrière un mot trop ordinaire. In Carpenter J., Horvath C. (dir.), Regards croisés sur la banlieue, Peter Lang, Bruxelles. p. 23-38.

Després C., Fortin A., Vachon G., 2001. La banlieue, patrimoine ? Quelques éléments de réflexion. Québec, Patrimoine, p. 25-28.

Di Méo G., 1994. Patrimoine et territoire, une parenté conceptuelle. Espaces et société, nº78, 1994/4

Djament-Tran G., 2014. La métropolisation de la culture et du patrimoine. Paris, Ed. Le Mansucrit ;

Donzelot J., 2006. Quand la ville se défait : une politique face à la crise des banlieues. Seuil.

Douay N., Prevot M., 2012. Numéro spécial « Activismes urbains ». L’information géographique, vol. 76/2 et vol 76/3.

Dufaux F., Gervais-Lambony Ph, 2009. Justice spatiale. Annales de Géographie, 2009/1, n 665-666.

Dufaux F., Fourcaut A. (dir.), 2004. Le monde des grands ensembles. Paris, Créaphis, 288 p. 
Fairclough G., Dragicevic Sesic M., Rogac Mijatovic L., Auclair E., Soini K., 2014. The Faro Convention, a new paradygme for socially - and culturally- sustainable heritage action? Kyлtypa/ Culture $n^{\circ} 8$ (journal for cultural researches, publié par MI-AN Publishing, Centre for Culture and Cultural Studies, Skopje, République de Macédoine).

Fourcaut A., 2000. Pour en finir avec la banlieue. Géocarrefour, vol. 75, n 75/2, p. 101-105.

Fourcaut A., 2007. Les quartiers populaires ont aussi une histoire. Projet, 2007/4, 299, p. 7-15

Frère.B, Jacquemain M., 2013. Résister au quotidien? Les Presses de Sciences Po.

Gazeau S (dir), 2012. Les projets participatifs au cœur de la (politique de la) ville. Art factories/ autrepArt(s).

Gravari-Barbas M. (dir), 2004. Habiter le patrimoine. PUR.

Gravari-Barbas M. (dir.), 2014. Nouveaux défis pour le patrimoine culturel. Atelier de Réflexion Prospective, Rapport final, ANR.

Groueff S., 2014. Militantisme patrimonial en banlieue. Urbanisme, 369, p. 39-41.

Hameth Ba A., Zentelin J.-L. (dir), 2010. La dimension culturelle du développement. Dynamiques de valorisation et de dévalorisation des territoires urbains. L'Harmattan.

Hamon F., 2007. Grands ensembles, demande de patrimonialisation et base Mérimée. Histoire urbaine, 2007/3 n² 20, p. 125-132. http://www.metropolitiques.eu/Faut-il-patrimonialiser-lesgrands.html

Hatzfeld H., 2014. La participation, une histoire ancienne. Urbanisme, 392, p. 32-35.

Healey P., 2003. Collaborative Planning in Perspective. Planning Theory, 2/101 - SAGE.

Healey P., 1997. Collaborative planning, shaping places in fragmented societies. Vancouver, University of British Columbia Press.

Heinich N., 2009. La fabrique du patrimoine. De la cathédrale à la petite cuillère. Éditions de la Maison des Sciences de l'Homme, coll. Ethnologie de la France, $286 \mathrm{p}$.

Hertzog A., 2014. Habiter la ville en transformation. Rénovation urbaine et mobilisation habitante à Vitry sur Seine: art, mémoire et activisme urbain. In Desponds D., et al. Les habitants, acteurs de la rénovation urbaine. PUR.

Hertzog A., 2011. Les géographes et le patrimoine. EchoGéo [En ligne], 18 | 2011, mis en ligne le 05 décembre 2011. URL : http://echogeo.revues.org/12840 ; DOI : 10.4000/echogeo.12840

Lefebvre, H., 1968. Le Droit à la ville. Anthropos (2 ed.), Paris, Ed. du Seuil.

Lussault M., 2009. De la lutte des classes à la lutte des places. Grasset.

Lussault M., 2007. L'homme spatial, la construction sociale de l'espace humain. Seuil.

Luxembourg C., 2014. Métamorphose des villes industrielles. Vivre la ville désindustrialisée.

L'Harmattan.

Melé P., 2004. Habitants mobilisés et devenir d'un espace patrimonial ? Géocarrefour [En ligne], vol. 79/3 | 2004, mis en ligne le 12 mars 2008, consulté le 22 septembre 2015. URL : http:// geocarrefour.revues.org/734

Melé P., 2013. Conflits de proximité et dynamiques urbaines. Rennes, PUR.

Merlin P., 2002. Les banlieues. PUF. 
Nussbaum, M., 2011. Capabilités, comment créer les conditions d'un monde plus juste ? Paris, Climats.

Paquot Th., Younes C. (dir.), 2007. Habiter le propre de l'humain. La Découverte.

Poirrier, P. (dir), 2010. Politiques et pratiques de la culture. La Documentation française, 2010.

Pouvreau B., 2011. Faut-il « patrimonialiser » les grands ensembles ? Métropolitiques, 28 mars. URL : http://www.metropolitiques.eu/Faut-il-patrimonialiser-les-grands.html

Rautenberg M., 2003. La rupture patrimoniale. À la croisée, Bernin.

Ripoll F., 2008. Espaces et stratégies de résistance : répertoire d'action collective dans la France contemporaine. Espace et sociétés, $\mathrm{n}^{\circ}$ 134, p. 83-97.

Stébé J.-M., 2010. La crise des banlieues, sociologie des banlieues sensibles. PUF.

Tricot A., 2014. L'habitant, un « amateur » d'espace ? Réflexions théoriques et méthodologiques pour une analyse de la perception sensible de l'environnement et du risque. In Ferrié J-N, Tournay V., Weisbein J., (dir), La consistance des êtres collectifs échanges pragmatiques et enjeux épistémologiques. Herman.

Urfalino P., 2004. L'invention de la politique culturelle. Hachette.

Verret M., 1984. Mémoire ouvrière, mémoire communiste. Revue Française de Science Politique, nº 3, p. 413-427.

Veschambre V., 2000. Firminy-Vert et le "site Le Corbusier". Vers une esthétisation du grand ensemble ? Cahiers de la Méditerranée, $\mathrm{n}^{\circ} 60,1$, 2000. Paysages urbains (XVIe-XXe siècles). Tome II [Actes du colloque de Grasse, décembre 1998] p. 133-156.

Veschambre V., 2008. Traces et mémoires urbaines, enjeux sociaux de la patrimonialisation et de la démolition. Rennes, Presses universitaires de Rennes.

Vieillard Baron H., 2001. Les banlieues, des singularités françaises aux réalités mondiales. Paris, Hachette Supérieur.

Young J.-E., 1992. The Counter-Monument. Memory against Itself in Germany. Critical Inquiry, 18, p. 267-296.

Zembri, P., 2005. Les nouvelles périphéries urbaines : pour une relativisation de la notion classique de banlieue. In Bertucci M.M., Houdard Mérot, V. (dir), Situations de Banlieue, Lyon, INRP.

\section{NOTES}

1. Following the Paris terrorist attacks in January 2015, French Prime Minister Manuel Valls used the expression «territorial, social and ethnic apartheid » to describe the situation of a number of regions, thus generating a fair share of controversy around his use of the term apartheid.

2. 1,300 priority areas are defined by Law $n^{\circ} 2014-173$ of the 21st February 2014 for urban planning and social cohesion.

3. Law $n^{\circ} 2010-597$ of the 3rd June 2010 on Greater Paris.

4. In France as in the rest of the world: heritage-making processes have become increasingly globalized, although they remain uneven and variously structured depending on the local context.

5. In the sense that it also involve an individual's emotions, sensations, aesthetical sense, perception of the material environment and use of objects. 
6. The European Council's conventions (2000 European convention on landscape, 2005 Faro convention on the value of cultural heritage for society) and the Unesco's white papers and conventions (2005 convention on cultural diversity, 2011 recommendation on historic urban landscapes) have encouraged States to see heritage not just as a collection of objects to be preserved but as a process, where everyday heritage plays a significant part and residents are expected to take an active part in the implementation of heritage projects and policies.

\section{INDEX}

Subjects: Sur le Champ - Sur le Terrain

\section{AUTHORS}

\section{ELIZABETH AUCLAIR}

Elizabeth Auclair, elizabeth.auclair@u-cergy.fr is a Senior Lecturer in Urban Planning at the University of Cergy-Pontoise. She is the Director of the Masters Program on Cultural and Heritage Development, and a member of the MRTE Laboratory. She has recently published: - Auclair E., 2015. Ordinary heritage, participation and social cohesion in the banlieues of Paris. In Auclair E., Fairclough G., (dir), Theory and practice in heritage and sustainability: living between past and future. London, Routlege, Studies in Culture and Sustainable Development.

- Auclair E., 2014. Artistes, habitants et démolition : le rôle des projets culturels dans la rénovation urbaine. In Desponds D., Auclair E., Bergel P., Bertucchi M.-M. (dir), Les habitants, acteurs de la rénovation urbaine? Rennes, PUR.

- Auclair E., 2014. Les projets mémoriels en banlieue : participation ou instrumentalisation des habitants? Revue Francosphères, $n^{\circ} 3-2$.

\section{ANNE HERTZOG}

Anne Hertzog, hertzog.anne@wanadoo.fr is a Senior Lecturer in Geography at the University of Cergy-Pontoise and a member of the MRTE Laboratory. She has recently published:

- Hertzog A., 2015. The challenge of cultural sustainability in city museums: Showing the city and selecting past in Noyon (France). In Auclair E., Fairclough G., Theory and Practice in Heritage and Sustainability: Between past and future. London, Routledge, Studies in Culture and Sustainable Development.

- Hertzog A., 2014. Reinventing battlefield tourism « in time of peace » : connecting tourism and violence. In Andrews Hazel, Tourism and violence. Ashgate Publishing Ldt.

- Hertzog A., 2014. Le musée d'art contemporain de banlieue, un nouveau territoire du tourisme en périphérie métropolitaine ? Le Mac/Val de Vitry sur Seine. In Gravari-Barbas M., Tourisme et Métropolisation. Une approche parisienne. Belin, coll. Mappemonde. 